\title{
The Role of HLA-antigens in Prurigo Hebra
}

\author{
Siti Aisah Boediardja," Moeslichan S, Santoso Cornain, ${ }^{f}$ Unandar Budimulja, ${ }^{\#}$ Adhi Djuanda ${ }^{\#}$
}

\begin{abstract}
Abstrak
Human leucocyte antigens (HLA) kelas I baik group A maupun B telah diketahui mempunyai hubungan dengan beberapa penyakit kulit, di antaranya psoriasis, dermatitis herpetiformis Duhring, dan lupus eritematosus. Pada penelitian terdahulu prurigo Hebra (PH) telah diketahui diturunkan secara genetik mengikuti pola penurunan multifaktor. Selain itu penderita PH sangat sensitif terhadap gigitan nyamuk, sehingga diduga terjadinya penyakit berkaitan dengan faktor imunogenetik, yaitu HLA. Makalah ini mengemukakan hasil penelitian kasus-kontrol mengenai hubungan HLA kelas I dengan PH yang dilakukan di Subbagian Ilmu penyakit Kulit dan Kelamin. FKUI-RSCM Jakarta. Subyek penelitian mencakup 41 PH dan 41 orang sehat sebagai kontrol. Pemeriksaan antigen HLA dilakukan berdasarkan teknik mikrolimfositotoksik menggunakan piring Terasaki yang dilengkapi antigen HLA kelas I untuk orang Asia buatan pabrik One Lambda, USA 1997. Berdasarkan frekuensi antigen (fa) ditemukan HLA-A9 $(f a=0.646)$ dan $H L A-B 15$ (fa-548) merupakan tipe HLA yang terbanyak ditemukan, sesuai dengan tipe HLA orang Indonesia. HLAAlO ditemukan lebih banyak pada $P H$, dan dianggap sebagai faktor risiko bermakna pada $P H$, risiko relatif $(R R)=8$, interval kepercayaan (IK) 95\% pada 1.67;38.87, dengan fraksi etiologinya sebesar 25,60\%. HLA-A6602(10) dan HLA-B27 kedua-duanya ditemukan sebagai faktor risiko bermakna untuk terjadinya $P H$ yang ringan, $R R=0,10$ dengan K.I.95\% pada 0.01-0.95. Sedangkan $H L A-B 63(15)$, walaupun tidak bermakna cenderung bermanifestasi sebagai $P H$ berat dengan $R R=5.55$. Pada penelitian ini tanpa diduga ditemukan $H L A-B 35$ dengan $R R=0,17, I . K .95 \%$ pada 0.04:0.65, sebagai faktor protektif terhadap terjadinya $P H$. Penemuan beberapa antigen HLA pada PH memperkuat hasil penemuan pola penurunan genetik multifaktor.
\end{abstract}

\begin{abstract}
Class-I human leucocyte antigens (HLA) group $A$ and $B$ have been investigated and associated with various skin diseases, such as psoriasis, herpetiformis dermatitis of Duhring, and lupus erythematosus. In earlier study, the genetic inheritance of prurigo Hebra $(P H)$ has been analyzed and it followed the pattern of multifactorial trait. All of $P H$ patients had hypersensitivity reactions to insect bite. These findings assumed that HLA antigens might have an association with PH. The purpose of this study is to investigate Class1 HLA antigens in PH patients. An unmatched case-control study was performed in 41 patients with PH and 41 normal healthy persons (control group). The class I-HLA was investigated based on microlymphocytotoxicity method using Terasaki plate completed with Class-1 HLA antigens for Asian (One Lambda, USA 1997). From the antigen frequency (fa) of HLA investigation, HLA-A9 $(f a=0.646)$ and $H L A-B 15(f a=0.548)$ types, were found more frequent among the population study $(n=82)$, and it was consistent with the characteristics of class 1-HLA types of the Indonesian population. In this study HLA-A10 was found significantly more frequent in PH patients than in the control group (RR-8.0 with 95\% C.I. 1.67; 8.87). HLA-A10 was concluded as a risk factor for PH, with the etiologic fraction 25.60\%. HLA-A6602(10) and HLA-B27 were significantly found as risk factors that influenced the development of mild PH $(R R=0.10$ with $95 \%$ C.I. 0.01; 0.95). Individuals with $H L A-B 63(15)$ clinically tend to develop severe $P H(R R=5.55$, although statistically was not significant). Interestingly, HLA-B35 was found more frequent in the control group than in PH patients $(R R=0.17,95 \%$ C.I. 0.04;0.65). HLA-B35 was concluded to be a significant protective factor for the development of PH. This study proved that HLA antigens are associated with PH and influence the severity of the disease. The polymorphic genes (multigenes) of HLA found in this study supported the theory that PH inheritance pattern is compatible with the multifactorial pattern.
\end{abstract}

Keywords: HLA, prurigo Hebra, HLA-A10, risk factor, HLA-B35, protective factor.

Prurigo Hebra (PH) is a chronic skin disease occuring mostly in children and young adults. It affects the

\footnotetext{
"Department of Dermato-venereology, Faculty of Medicine, University of Indonesia, Jakarta, Indonesia.

* Cytology Laboratory and HLA-transplantation, Faculty of Medicine, University of Indonesia, Jakarta, Indonesia.

$f$ Laboratory of Immunology, Department of Anatomic Pathology/Research Center for Medical Science and Technology, Faculty of Medicine, University of Indonesia, Jakarta, Indonesia.
}

face, extensors of the lower and upper extremities, sometimes extending to the buttocks and the abdomen. ${ }^{1-5}$ No systemic organ is involved. Considering the frequent occurrence in some families, the hypersensitivity to insect bite, bad hygiene and poor nutrition, a lot of authors suggested the genetic inheritance of $\mathrm{PH}$ may follow the multifactorial inheritance pattern. ${ }^{1-5}$ 
In earlier study, the genetic inheritance of 50 cases of $\mathrm{PH}$ with family tracing in three generations suggested that the genetic inheritance of $\mathrm{PH}$ followed the multifactorial pattern. There was no correlations between the severity of the disease and duration of illness. The possibility of mutation was excluded in statistical analysis. ${ }^{6}$ This study showed that some family members were affected and had hypersensitivity to some allergens, especially insect bite. It was assumed that the immunogenetic factors, namely HLA, may be associated with or play a role in the development of $\mathrm{PH}$.

Many experties indicated the association of class IHLA and class-II HLA with a certain degree of relative risks (RR) of skin diseases ${ }^{9-12}$ The results of these evidences varied, i.e. HLA-A8 is correlated with Duhring ( $R R=4.3), \quad H L A-B 27$ and HLA-B17 are associated with psoriasis, $R R=4$ and 8 , respectively. ${ }^{10,11}$ HLA-DR3 is correlated with cutaneous lupus erythematosus $(R R=4.3){ }^{10,11}$ The purpose of this study is to investigate the association between Class-1 HLA and prurigo Hebra.

\section{MATERIALS AND METHODS}

An unmatched case-control study design with ratio 1:1 was applied in this assessment. The study population consisted of males and females (unpregnant) age 5-30 years, investigated during May 1997 until July 1998, in outpatients clinic Department of Dermato-Venereology Dr. Cipto Mangunkusumo Central Hospital (RSCM), Jakarta.

The patients were defined as $\mathrm{PH}$ patients with active skin manifestation without other disease or systemic organ involvement. They had to be free from topical and systemic corticosteroid administration two weeks prior to the study. The severity score of $\mathrm{PH}$ was defined as the total score of lesion distribution plus density of lesions. The involved areas such as the lower and upper extremities, face, buttocks and abdomen, each part was scored $=1$. The density of lesions score was defined as: 1 meaning rare, $2=$ scanty, $3=$ full. The clinical severity was classified as mild if the total score was 8 or less and severe if the total score was 9 or more.

Control group were defined as normal healthy persons who came to the hospital for paternity test or donor test for kidney or bone marrow transplantation or persons who worked in the hospital, with age 5-30 years. This study recruited 41 cases and 41 controls ( $\alpha$ $=0.05$, statistical power $80 \%, R R=7$ ).

Class I-HLA, namely HLA-A and HLA-B, were investigated using HLA-class I Asian dry tray lot \# $1 A$ (antigen) made by One Lambda, USA $1997,{ }^{12}$ the reaction was based on the microlymphocytotoxicity reaction. ${ }^{9,14-16}$ Chi-square test or Fisher's exact test was performed to compare the antigen frequency of HLA-A and HLA-B antigens of case and control groups." Statistical analysis was calculated using SPSS program for Windows release 6.0.

\section{RESULTS}

Forty one $\mathrm{PH}$ patients and 41 normal healthy persons were eligible in this study. Prurigo Hebra group consisted of 18 children of $5-18$ years old and 23 adults of 19-30 years of age. The control group consisted of 3 children of 5-18 years old and 38 adults of 19-30 years of age. The mean age (years) of the PH group was $18 \pm 7$, while in the control group $22 \pm 4$ years. Statistically age distribution in these two groups was comparable. The sex distribution of $41 \mathrm{PH}$ patients (8 males and 33 females) and the control group (17 males and 24 females) was significantly differenece $(p<0.05, R R=2$ with $95 \%$ C.I. $=0.127 ; 0.922$ ).

The duration of ilness varied from 1-22 years, the mean duration was 9 and the median was 7 . Seven of 41 cases suffered from PH for more than 15 years, 14 for 10-14 years, and 20 persons suffered for less than 10 years. The onset of $\mathrm{PH}$ was usually at the age of one year, but mostly before the age of 14 years, 7 cases developed PH after the age of 14 years.

The severity scores ranged from 5 to 13 with mean score 8.6 and the median was 9 . We found one severe case with attach score 13 and duration of illness 2 years, while in the mild cases with the total score was $\leq 8$ and the duration of illness was not consistent. The correlation $(r)$ between the score of severity and the duration of illness was 0.20 (Spearmann's correlation) with $95 \%$ C.I. $-0.114 ; 0.479$.

\section{A. Class I- HLA-A}

\section{HLA-A types and its splits in the population study}

The results of HLA type and its subtype (split) investigations of all members of the population study 
$(n 1=n 2=41)$ are shown in the appendix. Twelfe types of HLA-A were found in 82 subjects. The antigen frequency (fa) and genetic frequency ( $\mathrm{fg}$ ) of 7 most common class I-HLA-A types are given in Table 1. Other HLA-A1, A23(9), A28, A30,A32, were found in few cases. HLA-A6602(10) is a split (subtype) of HLA-A10. In 1990 this split was named HLAAw66(10) and was not yet established, but then Moeslichan did not find the HLA-A6602(10). ${ }^{9}$ And other split of HLA-A10 (unknown type) could not be identified by the HLA-class I Asian dry tray lot \# $1 A$ used in this study.

\section{The correlation between HLA-A types and prurigo} Hebra

The correlation of HLA-A10 and its splits with PH are shown in Table 1. The HLA-A10 antigen was found frequently in $\mathrm{PH}$ patients (12) than in the control group (2). The coefficient correlation was high and significant RR was 8.0. The prevalence of $\mathrm{PH}$ in Dr. Cipto Mangunkusumo Hospital was $100 / 8000(1.25 \%)$ a year. If the prevalence in Indonesian population resemble as in Dr. Cipto Mangunkusumo Hospital, then the attributable risk (AR) or the true risk of those with HLA-A10 would be $12 / 2 \times 1.25 \%=7.5 \%$. The HLA-A10 etiologic fraction (EF) was $7 / 8 \times 12 / 41 \times 100 \%=25.60 \%$. The etiologic fraction (EF) formula was defined as follows ${ }^{17}$ :

$$
\mathrm{EF}=\frac{\mathrm{RR}-1}{\mathrm{RR}} \mathrm{x} \text { the risk factor in case (\%) }
$$

Other subtypes/splits-of HLA-A10 (unknown subtypes/could not be identified in this study), were found in 7 cases of $\mathrm{PH}$ and 1 in control group, analysis revealed $R R$ was 8.24 with $95 \%$ C.I. $=0.96$ (almost 1);70.3. The powers of correlation (r) between HLA-A6602(10) and HLA-A10 compared to the correlation between HLA-A10 and other splits of HLA-A10 were analysed. The formula was defined as follows ${ }^{11}$ :

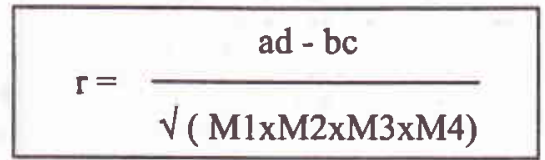

$r=$ correction coefficient of 2 related antibodies in 2 $\mathrm{x} 2$ table of Chi-square

This analysis showed that the correlation between HLA-A6602(10) and HLA-A10 ( $r=0.54)$ was stronger

Table 1. The HLA-A types in prurigo Hebra and control groups

\begin{tabular}{|c|c|c|c|c|c|c|c|c|c|c|}
\hline \multirow{2}{*}{\multicolumn{2}{|c|}{ HLA - A types }} & \multicolumn{3}{|c|}{ PH $(n 1=41)$} & \multicolumn{3}{|c|}{ Control $(\mathrm{n} 2=41)$} & \multirow[t]{2}{*}{$\mathbf{r}$} & \multirow[t]{2}{*}{$\mathbf{R R}$} & \multirow[t]{2}{*}{ 95\% C.I. } \\
\hline & & $\Sigma$ & fa & fg & $\Sigma$ & $\mathbf{f a}$ & fg & & & \\
\hline 1. HLA-A2 & $\dot{-}$ & $\begin{array}{l}28 \\
13\end{array}$ & 0.317 & 0.174 & $\begin{array}{l}27 \\
14\end{array}$ & 0.341 & 0.189 & 0.03 & $\begin{array}{c}1 \\
0.89\end{array}$ & $\begin{array}{l}\text { reference } \\
0.35 ; 2.25\end{array}$ \\
\hline 2. HLA-A9 & $\dot{+}$ & $\begin{array}{l}16 \\
25\end{array}$ & 0.609 & 0.375 & $\begin{array}{l}12 \\
29\end{array}$ & 0.707 & 0.459 & 0.13 & $\begin{array}{l}1 \\
0.58\end{array}$ & $\begin{array}{c}\text { reference } \\
0.24 ; 1.46\end{array}$ \\
\hline $\begin{array}{l}\text { 3. HLA-A24 } \\
\text { (9) }\end{array}$ & + & $\begin{array}{l}18 \\
23\end{array}$ & 0.561 & 0.338 & $\begin{array}{l}13 \\
28\end{array}$ & 0.682 & 0.450 & -0.13 & $\begin{array}{l}1 \\
0.59\end{array}$ & $\begin{array}{c}\text { reference } \\
0.24 ; 1.46\end{array}$ \\
\hline 4. HLA-A10* & + & $\begin{array}{l}29 \\
12\end{array}$ & 0.293 & 0.160 & $\begin{array}{l}39 \\
2\end{array}$ & 0.048 & 0.025 & 0.32 & $\begin{array}{l}1 \\
8.06\end{array}$ & $\begin{array}{c}\text { reference } \\
1.67 ; 8.87^{\star}\end{array}$ \\
\hline $\begin{array}{l}\text { 5. HLAA6602 } \\
\text { (10) }\end{array}$ & + & $\begin{array}{l}36 \\
5\end{array}$ & 0.121 & $\mathbf{0 . 0 6 3}$ & $\begin{array}{l}40 \\
1\end{array}$ & 0.024 & 0.020 & 0.18 & $\begin{array}{c}1 \\
5.55\end{array}$ & $\begin{array}{c}\text { reference } \\
0.61 ; 49.82\end{array}$ \\
\hline 6. HLA-A11 & + & $\begin{array}{l}27 \\
14\end{array}$ & 0.341 & 0.189 & $\begin{array}{l}29 \\
12\end{array}$ & 0.293 & 0.160 & 0.05 & $\begin{array}{l}1 \\
1.25\end{array}$ & $\begin{array}{l}\text { reference } \\
0.49 ; 3.18\end{array}$ \\
\hline 7. HLA-A33 & $\dot{+}$ & $\begin{array}{l}33 \\
8\end{array}$ & 0.195 & 0.103 & $\begin{array}{l}32 \\
7\end{array}$ & 0.171 & 0.089 & 0.03 & $\begin{array}{l}1 \\
1,17\end{array}$ & $\begin{array}{c}\text { reference } \\
0.38 ; 3.62\end{array}$ \\
\hline
\end{tabular}

Note: $\quad \mathrm{PH}=$ prurigo Hebra, fa = antigen frequency, $\mathrm{f} g=$ gen frequency, $\mathrm{r}=$ correlation coeffisient, $\mathrm{RR}=$ relative risk, $95 \%$ C.I. $=95 \%$ confidence interval, "Significance difference at $\mathrm{p} \leq 0.05$ 
than the correlation between the splits-HLA-A10 and HLA-A10 $(r=0.48)$.

\section{The significant correlation of HLA-A types and the severity of prurigo Hebra}

The correlation among three types of HLA-A and the severity of illness was evaluated by scatter diagram and chi-square test. The correlation between HLA-A10 and the severity of illness is given in Scatter diagram-1.

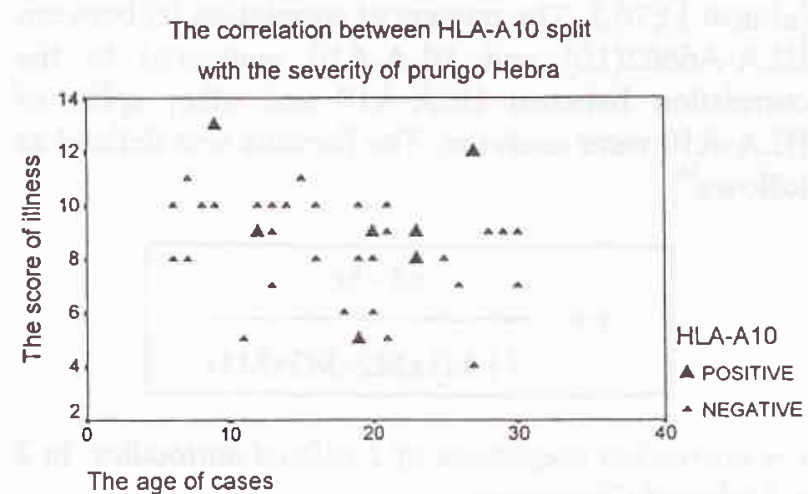

Scatter diagram-1.

Scatter diagram-1 shows the score of $\mathrm{PH}$ cases with HLA-A 10,6 out of 12 scored more than 8 (severe cases) and 6 scored less than 8 (mild cases).

The correlation between HLA-A10 split and the severity of illness is given in Scatter diagram-2. It shows the score of 7 PH cases with HLA-A10 (split), two cases scored $\leq 8$ (mild) and 5 scored $>9$ (severe).

The correlation between HLA-A6620(10) and the severity of illnessis given in Scatter diagram-3. Five cases of PH with HLA-A6602 (10) scored less than 8.
The correlation between HLA-A10 and HLAB6602(10) and the severity of PH, resulted by Chisquare analysis is shown in Table 2.

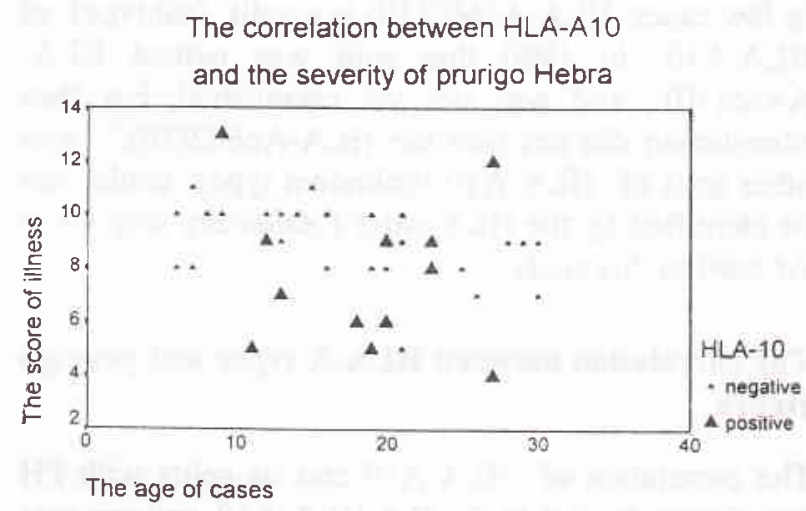

Scatter diagram-2.

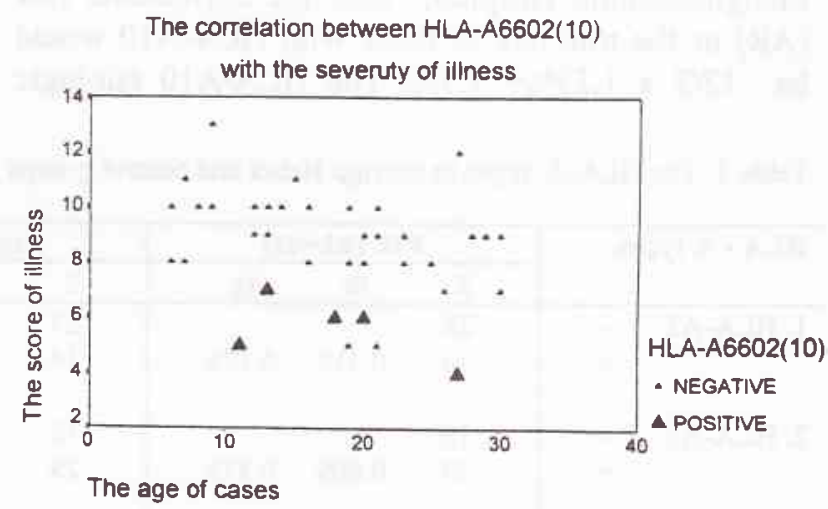

Scatter diagram-3.

Table 2. The correlation of HLA-A10 split and HLA-6602(10) and the severity of prurigo Hebra

\begin{tabular}{|c|c|c|c|c|c|c|c|c|}
\hline \multirow{2}{*}{\multicolumn{2}{|c|}{ HLA -A types }} & Severe $\geq 9$ & Mild $\leq 8$ & \multirow[t]{2}{*}{$\mathrm{X}^{2}(f)$} & \multirow[t]{2}{*}{ p } & \multirow[t]{2}{*}{$\mathbf{r}$} & \multirow[t]{2}{*}{$\mathbf{R R}$} & \multirow[t]{2}{*}{ 95\% C.I. } \\
\hline & & $(n=24)$ & $(n=17)$ & & & & & \\
\hline HLA-A6602(10) & $\dot{+}$ & $\begin{array}{r}24 \\
0\end{array}$ & $\begin{array}{r}12 \\
5\end{array}$ & $\begin{array}{l}8.3 \\
\text { (RR esti }\end{array}$ & $\begin{array}{l}<0.05 \\
\text { mation) }\end{array}$ & -0.44 & $\begin{array}{l}1 \\
0.10\end{array}$ & $\begin{array}{l}\text { reference } \\
0.01 ; 0.95^{*}\end{array}$ \\
\hline HLA-A10 (split) & + & $\begin{array}{r}19 \\
5\end{array}$ & $\begin{array}{r}15 \\
2\end{array}$ & 0.57 & $>0.05$ & 0.11 & $\begin{array}{l}1 \\
1.97\end{array}$ & $\begin{array}{l}\text { reference } \\
0.33 ; 11.6\end{array}$ \\
\hline
\end{tabular}

Note $\quad: \mathrm{X}^{2}=$ critical value $\mathrm{r}=$ coefficient correlation, $f=$ Fisher's exact test, $\mathrm{RR}=$ relative risk, $95 \%$ C.I. $=95 \%$ confidence interval *Significant difference at $\mathrm{p} \leq 0.05$ 
The results revealed that out of $7 \mathrm{PH}$ cases with HLAA10split, 2 had a mild condition and 5 manifested severe illness. All PH cases with HLA-A6602(10) developed a mild condition, the coefficient correlation was -0.44 , with significant $R R=0.10$.

\section{B. HLA-B and prurigo Hebra}

\section{HLA-B types and its splits in prurigo Hebra}

In this study 25 of Class-1 HLA-B types were found more polymorphic than HLA-A types as shown in Table 3. HLA-B15 was found as the highest frequency $(\mathrm{fa}=0.548)$, and higher than in the Indonesian population (1990) $(\mathrm{fa}=0.413) .{ }^{9}$ Other HLA-B types and splits, namely HLA-B75(15), HLAB35, HLA-B5, HLA-B27, HLA-B17, HLA-B40, and HLA-B60(40) were found in high frequency $(\geq 5)$, while the rest were low.

Table 3, shows that HLA-B63(15) (a splits of HLA$\mathrm{B} 15)$ was found in $5 \mathrm{PH}$ cases and 1 in the control group, $R R=5.55$, statistically was not significant.

HLA-B27 was more frequently found in PH patients than in control group, the coefficient correlation was low, RR was 3.34 .

Surprisingly, HLA-B35 was found more frequent in controls than in $\mathrm{PH}$, statistical analysis revealed a highly significant difference at $p<0.01$, with high correlation coefficient, significant RR less than 1 . The antigen frequency of HLA-B35 was 0.195 , higher than the Indonesian population $(\mathrm{fa}=0.137){ }^{9}$

The correlation between HLA-B and the severity of prurigo Hebra

There were 24 cases of $\mathrm{PH}$ with severe condition and 17 with mild condition. The association of HLAB63(15) with the severity of PH is shown in Scatter diagram-4. The diagram shows that 5 cases with HLA-B63(15) had score $\geq 9$. It also showed that the younger the age, the severer the illness. Scatter diagram-5. demonstrates 5 patients with HLA-B27 had scores less than 8 and 1 case had score 10 .

The correlation between HLA-B types and the severity of the PH is shown in Table 5. Only HLAB27 showed a significant corelation $(r=-0.35), 5$ cases with HLA-B27 manifested severe prurigo Hebra. Four patients with HLA-B63(15) and 4 with HLA-B17, expressed severe condition, both with $R R=3.20$, but statistically was not significant.

HLA-Bw4 was found in 24 cases and 23 control, HLA-Bw6 was found in 33 cases and 31 control, statistically the difference between HLA-Bw4 and Bw6 in two groups was not significant $(p>0.05)$.

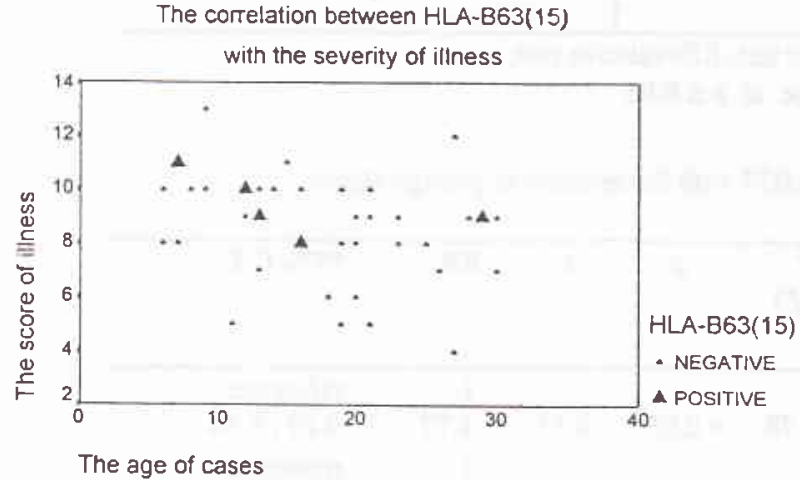

Scatter diagram-4.
Scatter diagram-5. 
Table 3. HLA-B types and its splits in prurigo Hebra and control $(n 1=n 2=41)$

\begin{tabular}{|c|c|c|c|c|c|c|c|c|c|c|}
\hline \multirow{2}{*}{\multicolumn{2}{|c|}{$\begin{array}{l}\text { HLA - B types } \\
\text { and its splits }\end{array}$}} & \multicolumn{3}{|c|}{ Case $(n 1=41)$} & \multicolumn{3}{|c|}{ Control (n2=41) } & \multirow[t]{2}{*}{$\mathbf{r}$} & \multirow[t]{2}{*}{$\mathbf{R R}$} & \multirow[t]{2}{*}{ 95\% C.I. } \\
\hline & & $\Sigma$ & fa & fg & $\Sigma$ & fa & fg & & & \\
\hline \multirow[t]{2}{*}{ 1. HLA-B5 } & - & 34 & & & 37 & & & & 1 & reference \\
\hline & + & 7 & 0.170 & 0.089 & 8 & 0.097 & 0.050 & 0 & 1 & $0.26 ; 3.75$ \\
\hline \multirow[t]{2}{*}{ 2. HLA-B51(5) } & - & 39 & & & 37 & & & & 1 & reference \\
\hline & + & 4 & 0.096 & 0.040 & 4 & 0.096 & 0.040 & 0 & 1 & $0.23: 4.30$ \\
\hline \multirow{4}{*}{$\begin{array}{l}\text { 3. HLA- } \\
\text { B44(12) } \\
\text { 4. HLA-B13 }\end{array}$} & - & 39 & & & 38 & & & & 1 & reference \\
\hline & + & 2 & 0.048 & 0.025 & 3 & 0.075 & 0.039 & 0.50 & 0.65 & $1.10 ; 4.10$ \\
\hline & - & 39 & & & 37 & & & & 1 & reference \\
\hline & + & 2 & 0.048 & 0.025 & 4 & 0.096 & 0.040 & 0.09 & 0.47 & $0.9 ; 2.74$ \\
\hline \multirow[t]{2}{*}{ 5. HLA-B15 } & - & 16 & & & 21 & & & & 1 & reference \\
\hline & + & 25 & 0.609 & 0.375 & 20 & 0.487 & 0.384 & 0.12 & 1.64 & $0.68 ; 3.94$ \\
\hline \multirow{2}{*}{$\begin{array}{l}\text { 6. HLA-B63 } \\
\text { (15) }\end{array}$} & - & 36 & & & 40 & & & & 1 & reference \\
\hline & + & 5 & 0.121 & 0.063 & 1 & 0.024 & 0.020 & 0.18 & 5.55 & $0.61 ; 49.82$ \\
\hline \multirow{4}{*}{$\begin{array}{l}\text { 7. HLA-B75 } \\
\text { (15) } \\
\text { 8. HLA-B77 } \\
\text { (15) }\end{array}$} & - & 29 & & & 31 & & & & 1 & reference \\
\hline & + & 12 & 0.292 & 0.159 & 10 & 0.243 & 0.130 & 0.05 & 1.28 & $0.48 ; 3.41$ \\
\hline & - & 40 & & & 38 & & & & 1 & reference \\
\hline & + & 1 & 0.024 & 0.020 & 3 & 0.075 & 0.039 & -0.11 & 0.31 & $0.03 ; 3.17$ \\
\hline \multirow{2}{*}{ 9. HLA-B16 } & - & 40 & & & 36 & & & & 1 & reference \\
\hline & + & 1 & 0.048 & 0.020 & 5 & 0.121 & 0.063 & 0.18 & 0.18 & $0.61 ; 49.82$ \\
\hline \multirow{4}{*}{$\begin{array}{l}\text { 10. HLA-B38 } \\
\text { (16) } \\
\text { 11. HLA-B17 }\end{array}$} & - & 40 & & & 37 & & & & 1 & reference \\
\hline & + & 1 & 0.048 & 0.020 & 4 & 0.096 & 0.040 & -0.15 & 0.23 & $0.23 ; 2.16$ \\
\hline & - & 36 & & & 38 & & & & 1 & reference \\
\hline & + & 5 & 0.121 & 0.063 & 3 & 0.075 & 0.039 & 0.09 & 1.75 & $0.03 ; 7.9$ \\
\hline \multirow{2}{*}{$\begin{array}{l}\text { 12. HLA-B57 } \\
\text { (17) }\end{array}$} & - & 40 & & & 41 & & & & 1 & reference \\
\hline & + & 1 & 0.048 & 0.020 & 1 & 0.048 & 0.020 & 0 & 1 & $0.06 ; 16.54$ \\
\hline \multirow[t]{2}{*}{ 13. HLA-B18 } & - & 38 & & & 38 & & & & 1 & reference \\
\hline & + & 3 & 0.075 & 0.039 & 3 & 0.075 & 0.039 & 0 & 1 & $0.18 ; 5.27$ \\
\hline \multirow[t]{2}{*}{ 14. HLA-B27 } & - & 35 & & & 39 & & & & 1 & reference \\
\hline & + & 6 & 0.146 & 0.076 & 2 & 0.048 & 0.025 & 0.16 & 3.34 & $0.63 ; 17.6$ \\
\hline \multirow[t]{2}{*}{ 15. HLA-B35 } & - & 38 & & & 28 & & & & 1 & reference \\
\hline & + & 3 & 0.075 & 0.039 & 13 & 0.317 & 0.174 & $\mathbf{0 . 3 0}$ & 0.17 & $0.04 ; 0.65^{\star}$ \\
\hline \multirow[t]{2}{*}{ 16. HLA-B40 } & - & 36 & & & 36 & & & & 1 & reference \\
\hline & + & 5 & 0.121 & 0.063 & 5 & 0.121 & 0.063 & 0 & 1 & $0.26 ; 3.75$ \\
\hline \multirow{2}{*}{$\begin{array}{l}\text { 17. HLA-B60 } \\
(40)\end{array}$} & - & 39 & & & 37 & & & & 1 & reference \\
\hline & + & 2 & 0.048 & 0.025 & 4 & 0.096 & 0.040 & 0.09 & 0.47 & $0.90 ; 2.74$ \\
\hline
\end{tabular}

Note: $\quad \mathrm{X}^{2}=$ critical value, $\mathrm{r}=$ correlation coefficient, $\mathrm{f}=$ Fisher's exact test, $\mathrm{RR}=$ relative risk, $95 \%$ C.I. $=95 \%$ confidence interval $*$ ) Significant difference at $\mathrm{p} \leq 0.05$

Table 4. Correlation between HLA-B15, HLA-B63(15), HLA-B17, HLAB27 with the severity of prurigo Hebra

\begin{tabular}{|c|c|c|c|c|c|c|c|c|}
\hline \multirow{2}{*}{\multicolumn{2}{|c|}{$\begin{array}{l}\text { HLA -B types and } \\
\text { its splits }\end{array}$}} & $\begin{array}{c}\text { Severe cases } \\
(\mathrm{n} 1=\mathbf{2 4})\end{array}$ & $\begin{array}{l}\text { Mild cases } \\
(\mathrm{n} 2=17)\end{array}$ & \multirow[t]{2}{*}{$\begin{array}{l}\mathrm{X}^{2} \\
(f)\end{array}$} & \multirow[t]{2}{*}{$\mathbf{p}$} & \multirow[t]{2}{*}{$\mathbf{r}$} & \multirow[t]{2}{*}{$\mathbf{R R}$} & \multirow[t]{2}{*}{ 95\% C.I. } \\
\hline & & Total & Total & & & & & \\
\hline HLA-B15 & $\overline{+}+$ & $\begin{array}{r}8 \\
16\end{array}$ & $\begin{array}{l}8 \\
9\end{array}$ & 0.78 & $>0.05$ & 0.13 & $\begin{array}{l}1 \\
1.77\end{array}$ & $\begin{array}{l}\text { reference } \\
0.29 ; 6.36\end{array}$ \\
\hline HLA-B63(15) & + & $\begin{array}{r}20 \\
4\end{array}$ & $\begin{array}{r}16 \\
1\end{array}$ & 1.08 & $>0.05$ & 0.16 & $\begin{array}{l}1 \\
3.20\end{array}$ & $\begin{array}{l}\text { reference } \\
0.32 ; 31.58\end{array}$ \\
\hline HLA-B 17 & $\dot{+}$ & $\begin{array}{r}20 \\
4\end{array}$ & $\begin{array}{r}16 \\
1\end{array}$ & 1.80 & $>0.05$ & 0.16 & $\begin{array}{l}1 \\
3.20\end{array}$ & $\begin{array}{l}\text { reference } \\
0.32 ; 31.53\end{array}$ \\
\hline HLA-B27 & + & $\begin{array}{r}23 \\
1\end{array}$ & $\begin{array}{r}12 \\
5\end{array}$ & 5.07 & $<0.05^{\star}$ & -0.35 & $\begin{array}{l}1 \\
0.10\end{array}$ & $\begin{array}{l}\text { reference } \\
0.01 ; 0.98\end{array}$ \\
\hline
\end{tabular}

Note $\quad: \mathrm{X}^{2}=$ critical value $\mathrm{r}=$ coefficient correlation, $f=$ Fisher's exact test, $\mathrm{RR}=$ relative risk, $95 \%$ C.I. $=95 \%$ confidence interval * significant difference at $\mathrm{p} \leq 0.05$ 


\section{DISCUSSION}

Sex distribution in $41 \mathrm{PH}$ cases showed that female was predominant and had an increased possibility greater twicethan male to suffer from PH. The sex liability findings in $\mathrm{PH}$ supported the genetic inheritance of multifactorial trait.

The age onset of PH was varied and not consistant with the normal curve. The correlation between the severity and the duration of illness was weak and not significant.

Table 1. shows HLA-A9, A2, and A11 were frequently found in this study as well as in the Indonesian population (1990). ${ }^{18}$ The antigen frequency (fa) of HLA-A9 $(\mathrm{fa}=0.646)$ in this study was higher than in Indonesians in $1990(\mathrm{fa}=0.625) .^{9}$ The antigen frequency (fa) of HLA-A10 (0.170) in this study was higher than that in the Indonesian control $(\mathrm{fa}=0.056),{ }^{9}$ while HLA-A11 $(\mathrm{fa}=0.317)$ was lower than in the Indonesians $(\mathrm{fa}=0.381){ }^{9}$

Considering the $r=0.32, R R=8.06$ (significant), there was a strong correlation between HLA-A 10 and prurigo Hebra. HLA-A10 was concluded as a significant risk factor for PH. Persons with HLAAl0 have an $8 \times$ greater possibility to suffer fromPH than those without HLA-A10. In this study, HLAA6602(10) was found in 5 cases of PH and one in the control group, RR was 5.55. Although statistically was not significant, but clinically it could be assumed that those individuals with HLA-A6602(10) have a tendency $5 \mathrm{x}$ greater to suffer from $\mathrm{PH}$.

Patients with HLA-A10, is shown in Scatter diagram 1, 5 of 10 cases manifested as mild PH (score $\leq 8$ ). Most cases (5) with HLA-A10 splits expressed severe condition (Scatter diagram 2). The significant correlation of HLA-A6602(10) and the severity was figure in Scatter diagram 3. and Table 2. It was assumed that $\mathrm{PH}$ patients with HLA-6602(10) clinically manifested as mild prurigo Hebra. HLAA6602(10) seems to be a protective factor or a factor that could reduce the grade of severity of I PH patients. Five out of 7 cases with HLA-A10 splits clinically developed severe condition (Scatter diagram 2), although statistically not significant (Table2). PH patients with HLA-A10 split has an increased risk twice as much to suffer from severe condition.

HLA-B63(15) was a split of HLA-B15. The coefficient correlation $(r=0.18)$ and the relative risk of HLA-
B63(15) was 5.55 higher than HLA-B15 ( $r=0.12$ with $R R=1.64$ ) (Table 3); it was assumed that HLAB63(15) had stronger correlation with prurigo Hebra than HLA-B15. Although RR of HLA-B63(15) was found not significant, but clinically it showed that persons with HLA-B63(15) have an increased possibility of $5.5 \mathrm{x}$ greater to suffer from prurigo Hebra than those without HLA-B63(15).

Although statistically was not significant patients with HLA-B63(15) or HLA-B17, both had a possibility $3 \mathrm{x}$ greater to develop severe prurigo Hebra. Scatter diagram 5. shows the correlation between the age of HLA-B63(15) and the severity, the younger the age, the severer the illness.

HLA-B27 was more frequently found in PH than in control, but the difference is not significant. Clinically HLA-B27 should be considered as a possible risk factor. Persons with HLA-B27 had a chance $3 \mathrm{x}$ more to suffer from PH than those without HLA-B27. The correlation between HLA-B27 and the severity was analyzed and concluded that most patients with HLAB27 developed mild prurigo Hebra. The onset of the disease in 4 of 5 cases with HLA-B27was before 10 years old, it was later than usual. HLA-B27 had a negative coefficient correlation $(-0.35)$ with significant $R R=0.10$, it was assumed to be a protective factor for severe $\mathrm{PH}$. Scatter diagram 5. Shows that $\mathrm{PH}$ patients with HLA-B27 manifest a mild condition than those without HLA-B27 $(p<0.05)$.

Surprisingly, that HLA-B35 was more frequently found in control group with $r=-0.30, R R=0.17$, and significant (Table-3). It is concluded that HLA-B35 acts as a significant protective factor against $\mathrm{PH}$, meaning those individuals with HLA-B35 might be protected from $\mathrm{PH}$.

The co-dominant effect of HLA was seen in one PH patient with both HLA-A10 and HLA-B63(15) and expressed severe condition (scores $=13$ ). The reduction effect of HLA-B27 was seen in a case with both HLA-A10 and HLA-B27 and manifested mild condition (scores $=8$ ).

\section{CONCLUSION}

We conclude that that there is a significant correlation between HLA-A10 and prurigo Hebra, HLA-A10 is a significant risk factor $(\mathrm{RR}=8)$ for prurigo Hebra. HLA-A6602(10) has a significant correlation with the 
severity of the disease ( $R R \quad 0.10)$. It is assumed that cases with HLA-A6602(10) will develop mild prurigo Hebra.

HLA-B27 has a significant correlation with the severity of illness, the significant RR was 0.10 . We conclude that HLA-B27 plays as a protective factor or may reduce the severity of PH. Prurigo Hebra with HLA-B27 will develop a mild condition. Contrary, HLA-B63(15) tends to be a risk factor $(R R=5.55$, not significant.), and potentially $3 \mathrm{x}$ developing severe condition. HLA-B17 tends to be a risk factor ( $R R=2$, not significant.) and prurigo Hebra with HLA-B17 tends to develop a severe condition $(\mathrm{RR}=3.2$ not significant). Statistically HLA-B35 plays as a significant protective factor for prurigo Hebra (RR of HLA-B35 $=0.17$ ).

In this study HLA as an immunogenetic factor was proved to have an association with $\mathrm{PH}$ and influence the development and severity of prurigo Hebra.

We conclude persons with HLA-A10 should be recommended to prevent exposure from mosquitoes bite in order to protect from suffering $\mathrm{PH}$, so are those with patients with splits of HLA-A10 and HLAB63(15) to prevent severer progression. The splits of HLA-A $10^{19}$ that have not been identified in this study by the HLA-class-I Asian dry tray should be reexamined with other antigens tray to investigate the specificity of these splits.

\section{Acknowledgment}

We are very grateful to $H$. Muh. Masykur and to Dra. Ratna Pudiantari for their great help in HLA examination.

\section{REFERENCES}

1. von Hebra F. Erythema multiforme, lichen simplex, prurigo, pityriasis rosea, rhinosklerosis. In: Shelley WB, Crissey JT, Stokes JH, Eds. Classics in clinical dermatology with biographical scketches. Oxford: Blackwell Scientific Publication; 1953. p. 110-2.

2. McKenna RW, Mc Kenna MW. Diseases of the skin. $6^{\text {th }}$ ed. London: Billaire Tindall and Cox; 1952. p. 331-52.
3. Ormsby DS, Montgomery H. Diseases of the skin. $6^{\text {th }}$ ed. Philadelphia: Lea \& Febriger; 1954. p. 197-203.

4. Rook A, Wilkinson DS, Ebling FJG. Eczema, lichen simplex and prurigo. In: Rook A, Ed. Rook's Textbook of Dermatology. London: Blackwell Scientific Publication; 1972. p. 84-9, 291-8

5. Amold HL, Odomm RB, James WD. Andrew's diseases of the skin: clinical dermatology, $8^{\text {th }}$ ed. Philadelphia: WB Sauders Company; 1990. p. 157-8.

6. Boediardja SA. Studi pola penurunan genetik, HLA kelas I, dan imunohistopatologik pada perkembangan lesi awal dan lanjut prurigo Hebra. A disertation. Jakarta: Balai Penerbit FKUI, 1999.

7. Gehlehrter TD, Colins Fs. Principle of medical genetics. Baltimore 1990. Williams and Wilkins. p. 1-68.

8. Thomson MW, Mc Innes RR, Willard HF. Thomson \& Thomson: Genetics in medicine. $5^{\text {th }}$ ed. Philadelphia 1991. WB Saunders Company .p. 349-63.

9. Moeslichan SMz. Penelitian sistem HLA dalam upaya memperoleh sumber antibodinya. Disertasi. Jakarta: Universitas Indonesia; 1990. h. 9-59, 61-95, 135.

10. Hall JR, Amett FC. The HLA system and cutaneous diseases. In: Jordon RE, Ed. Immunologic diseases of the skin. Connecticut: Appleton \& Lange; 1991 .p.101-12.

11. Festenstein $H$, De'mant $P$. HLA and H2: Basic immunogenetics, biology and classical relevance. London: Edward Amold. Ltd; 1978. p.16-84; 161-74.

12. Comain S. The significance of HLA antigens in Dermatology. Med J Indones, 1995; 4: 44-7.

13. Boenish T. Staining methods. In: Naish Sj. Handbook: immunological staining methods. Califomia: Dako cooperation; 1989. p. 13-23.

14. Jasani $\mathrm{B}$, Schmid $\mathrm{Kw}$. Immunocytochemistry in diagnostic histopathology. London: Churchil] Livingstone; 1993. p.1-27.

15. Yaoita $H$. Enzyme labelled antibody method. In: Ueki $H$, Yaoita H, Eds. A colour atlas of dermatohistocytology. Tokyo: Wolfe Medical Publications Ltd; 1989. p. 8-10.

16. Takezaki S, Nishiyama S. Application of monoclonal antibodies. In: Ueki H, Yaoita H, Eds. A colour atlas of dermatohistocytology. Tokyo: Wolfe Medical Publications Ltd.; 1989. p.18-23

17. Watanabe T, Ohishi M, Tanaka K, Sato H. Analysis of HLA antigen in Japanese with oral Lichen planus. J Oral Pathol 1986; 15: 529-33.

18. Batchelor JR, McMichael AJ. Proress in understanding HLA and disease association. In: Crumpton Ed. HLA in medicine. British Medical Bulletin, Volume forty-three, London 1987. Churchill Livingstone for the British Council. p. 157-183.

19. Nomenclature Committee. The new nomenclature. $12^{\text {th }}$ International Histocompatibility Workshop. $12^{\text {th }} \mathrm{W}$ Express 1995; 4:6-15. 
Appendix 1. TABLE. CLASS 1-HLA TYPES AND ITS SPLITS IN PRURIGO HEBRA
AND CONTROL (HEALTHY PERSONS) (n1=n2=41)

\begin{tabular}{|c|c|c|c|}
\hline NUMBER & HLA-TYPES IN PRURIGO HEBRA & NUMBER & HLA TYPES IN CONTROL \\
\hline 1. & A24(9), B15, Bw6 & 1. & $\mathrm{~A} 10, \mathrm{~A} 24(9), \mathrm{B} 13, \mathrm{~B} 15, \mathrm{Bw4}, \mathrm{Cw}-$ \\
\hline 2. & A11, A33, B5, B51, Bw4 & 2. & $\mathrm{~A} 2, \mathrm{~B} 39(16), \mathrm{Bw} 4, \mathrm{Cw}-5, \mathrm{Cw} 6$ \\
\hline 3. & $\mathrm{~A} 10, \mathrm{~B} 7, \mathrm{~B} 15, \mathrm{Bw} 6$ & 3. & A24(9), A6602(10), B35, Ag-ekstra, Bw6, Cw- \\
\hline 4. & $\mathrm{~A} 1, \mathrm{~A} 2, \mathrm{~B} 57(17), \mathrm{B} 63(15), \mathrm{Bw} 4, \mathrm{Cw}-$ & 4. & $\mathrm{~A} 2, \mathrm{~A} 24(9), \mathrm{B} 15, \mathrm{Bw} 6, \mathrm{Cw5}, \mathrm{Cw6}$ \\
\hline 5. & $\mathrm{~A} 24(9), \mathrm{A} 11, \mathrm{~B} 7, \mathrm{~B} 27, \mathrm{Bw4}, \mathrm{Bw6}, \mathrm{Cw}-$. & 5. & $\mathrm{~A} 24(9), \mathrm{B} 75(15), \mathrm{Bw} 4, \mathrm{Cw}-$ \\
\hline 6. & $\begin{array}{l}\mathrm{A} 24(9), \mathrm{A} 33, \mathrm{~B} 75(15), \mathrm{B} 17 \\
\mathrm{Bw} 4, \mathrm{Bw6}, \mathrm{Cw}-\end{array}$ & 6. & $\begin{array}{l}\mathrm{A} 24(90, \mathrm{~A} 11, \mathrm{~B} 38(16), \mathrm{B} 15 \\
\text { Bw4, Cw- }\end{array}$ \\
\hline 7. & $\mathrm{~A} 24(9), \mathrm{A} 11, \mathrm{~B} 18, \mathrm{Bw} 4, \mathrm{Cw}-$ & 7. & $\mathrm{~A} 24(9), \mathrm{B} 75(15), \mathrm{B} 35, \mathrm{Bw6}, \mathrm{Cw}-$ \\
\hline 8. & $\mathrm{~A} 24(9), \mathrm{A} 33, \mathrm{~B} 75(15), \mathrm{B} 17, \mathrm{Bw6}, \mathrm{Cw}-$ & 8. & $\mathrm{~A} 24(9), \mathrm{B} 75(15), \mathrm{B} 77(15), \mathrm{BW} 4, \mathrm{Bw6}, \mathrm{Cw}-$ \\
\hline 9. & $\begin{array}{l}\text { A24(9), B27, Bw4, Cw- } \\
\text { Ag-Ekstra }\end{array}$ & 9. & $\mathrm{~A} 2, \mathrm{~A} 11, \mathrm{~B} 38(16), \mathrm{B} 35, \mathrm{Bw} 4, \mathrm{Bw6}, \mathrm{Cw}-$ \\
\hline 10. & $\mathrm{~A} 24(9), \mathrm{A} 11, \mathrm{~B} 17, \mathrm{Bw4}, \mathrm{Bw6}, \mathrm{Cw}-$ & 10. & $\mathrm{~A} 1, \mathrm{~A} 24(9), \mathrm{B} 57(17), \mathrm{B} 40, \mathrm{Bw4}, \mathrm{Bw6}, \mathrm{Cw}-$ \\
\hline 11. & $\mathrm{~A} 10, \mathrm{~A} 33, \mathrm{~B} 75(15), \mathrm{B} 35, \mathrm{Bw6}, \mathrm{Cw}-$ & 11. & $\mathrm{~A} 11, \mathrm{~B} 44(12), \mathrm{B} 13, \mathrm{Bw} 4, \mathrm{Cw}-$ \\
\hline 12. & $\mathrm{~A} 24(9), \mathrm{B} 55(22), \mathrm{B} 27, \mathrm{Bw} 4, \mathrm{Bw6}, \mathrm{Cw}-$ & 12. & $\mathrm{~A} 24(9), \mathrm{B} 15, \mathrm{~B} 67, \mathrm{Bw6}, \mathrm{Cw}-$ \\
\hline 13. & $\mathrm{~A} 2, \mathrm{~A} 24(9), \mathrm{B} 75(15), \mathrm{B} 63(15), \mathrm{Bw} 4, \mathrm{Bw6}, \mathrm{Cw}-$ & 13. & $\mathrm{~A} 2, \mathrm{~A} 24(9), \mathrm{B} 77(15), \mathrm{B} 41, \mathrm{Bw} 4, \mathrm{Bw6}, \mathrm{Cw} 4$ \\
\hline 14. & $\mathrm{~A} 24(9), \mathrm{B} 38(16), \mathrm{B} 63(15), \mathrm{Bw} 4, \mathrm{Cw} 4$ & 14. & $\mathrm{~A} 2, \mathrm{~A} 11, \mathrm{~B} 53(5), \mathrm{B} 75(15), \mathrm{Bw} 4, \mathrm{Bw6}, \mathrm{Cw} 3, \mathrm{Cw5}$ \\
\hline 15. & $\mathrm{~A} 6602(10), \mathrm{B} 75(15), \mathrm{Bw} 6, \mathrm{Cw}-$ & 15. & $\mathrm{~A} 11, \mathrm{~A} 33, \mathrm{~B} 44(12), \mathrm{B} 15, \mathrm{Bw} 4, \mathrm{Bw6}, \mathrm{Cw}-$ \\
\hline 16. & $\mathrm{~A} 10, \mathrm{~A} 33, \mathrm{~B} 17, \mathrm{~B} 15, \mathrm{Bw} 4, \mathrm{Bw6}, \mathrm{Cw}-$ & 16. & $\mathrm{~A} 2, \mathrm{~A} 33, \mathrm{~B} 15, \mathrm{~B} 17, \mathrm{Bw} 6, \mathrm{Cw} 4$ \\
\hline 17. & $\mathrm{~A} 11, \mathrm{~A} 24(9), \mathrm{B} 51(5), \mathrm{B} 63(15), \mathrm{Bw} 4, \mathrm{Bw6}, \mathrm{Cw}-$ & 17. & $\mathrm{~A} 24(9), \mathrm{A} 33, \mathrm{~B} 13, \mathrm{~B} 44(12), \mathrm{Bw} 4, \mathrm{Cw}-$ \\
\hline 18. & $\mathrm{~A} 2, \mathrm{~A} 11, \mathrm{~B} 75(15), \mathrm{Bw6}, \mathrm{Cw}-$ & 18. & $\mathrm{~A} 24(9), \mathrm{A} 33, \mathrm{~B} 18, \mathrm{~B} 60(40), \mathrm{Bw6}, \mathrm{Cw}-$ \\
\hline 19. & A6602(10), Al1, B75(15), Bw6. & 19. & A9, B13, Ag-ekstra, BWw, Cw- \\
\hline 20. & $\mathrm{~A} 10, \mathrm{~A} 11, \mathrm{~B} 75(15), \mathrm{Bw} 4$ & 20. & $\mathrm{~A} 2, \mathrm{~A} 9, \mathrm{~B} 35, \mathrm{Bw} 6$ \\
\hline 21. & A2, A11, B18, B63(15), Bw4, Bw6 & 21. & $\mathrm{~A} 24(9), \mathrm{B} 35, \mathrm{~B} 17, \mathrm{Bs} 4, \mathrm{Bw6}$ \\
\hline 22. & $\mathrm{~A} 2, \mathrm{~B} 44(12), \mathrm{B} 63(15), \mathrm{Bw} 4$ & 22. & $\mathrm{~A} 24(9), \mathrm{B} 18+\mathrm{extr}, \mathrm{Bw6}$ \\
\hline 23. & $\mathrm{~A} 6602(10), \mathrm{A} 11, \mathrm{~B} 44(12), \mathrm{B} 60(40), \mathrm{Bw} 4, \mathrm{Bw6}$. & 23. & A2, A24(9), B35, B60(40), Bw6 \\
\hline 24. & $\mathrm{~A} 24(9), \mathrm{B} 27, \mathrm{~B} 52$ (5), Bw4, Cw2 & 24. & $\mathrm{~A} 24(9), \mathrm{B} 15, \mathrm{~B} 35, \mathrm{Bw} 6$ \\
\hline 25. & $\mathrm{~A} 24(9), \mathrm{B} 18, \mathrm{~B} 60(40), \mathrm{Bw6}, \mathrm{Cw} 2, \mathrm{Cw} 3$ & 25. & $\mathrm{~A} 24(9), \mathrm{A} 33, \mathrm{~B} 51(5), \mathrm{B} 35, \mathrm{Bw} 4, \mathrm{Bw} 6$ \\
\hline 26. & $\mathrm{~A} 2, \mathrm{~A} 24(9), \mathrm{B} 67, \mathrm{~B}, \mathrm{~B} 35, \mathrm{Bw6}, \mathrm{Cw} 2, \mathrm{Cw} 3$ & 26. & $\mathrm{~A} 2, \mathrm{~A} 24(9), \mathrm{B} 35, \mathrm{~B} 60(40), \mathrm{Bw} 6$ \\
\hline 27. & $\mathrm{~A} 6602(10), \mathrm{A} 24(9), \mathrm{B} 67, \mathrm{~B} 35, \mathrm{Bw} 4, \mathrm{Bw6}, \mathrm{Cw}-$ & 27. & A24(9), B35, B75(15), Bw6 \\
\hline 28. & $\mathrm{~A} 11, \mathrm{~A} 33, \mathrm{~B} 75(15), \mathrm{B} 13, \mathrm{~B} 61(40)$ & 28. & $\mathrm{~A} 24(9)$, , B75(15), Bw6 \\
\hline 29. & $\mathrm{~A} 11, \mathrm{~A} 33, \mathrm{~B} 75(15), \mathrm{Bw4}, \mathrm{Bw6}, \mathrm{Cw}-$ & 29. & $\mathrm{~A} 24(9), \mathrm{A} 33, \mathrm{~B} 15, \mathrm{~B} 44(12), \mathrm{Bw} 4, \mathrm{Bw} 6$ \\
\hline 30. & $\mathrm{~A} 24(9), \mathrm{A} 2, \mathrm{~B} 7, \mathrm{~B} 27, \mathrm{Bw} 4, \mathrm{Bw6}, \mathrm{Cw} 2$ & 30. & $\mathrm{~A} 11, \mathrm{~A} 32, \mathrm{~B} 7, \mathrm{~B} 60(40), \mathrm{Bw} 6$ \\
\hline 31. & A24(9), B51(5), B75(15), Ag-extra, Bw4, Bw6, Cw2 & 31. & $\mathrm{~A} 2, \mathrm{~A} 24(9), \mathrm{B} 7, \mathrm{~B} 27, \mathrm{Bw} 4, \mathrm{Bw} 6$ \\
\hline 32. & $\mathrm{~A} 2, \mathrm{~A} 10, \mathrm{~B} 15, \mathrm{~B} 69(40), \mathrm{Bw} 4, \mathrm{Bw} 6, \mathrm{Cw}-$ & 32. & $\mathrm{~A} 24(9), \mathrm{B} 16, \mathrm{~B} 27, \mathrm{Bw} 4$ \\
\hline 33. & $\mathrm{~A} 1, \mathrm{~A} 23(9), \mathrm{B} 8, \mathrm{~B} 15, \mathrm{Bw6}, \mathrm{Cw}-$ & 33. & $\mathrm{~A} 24(9), \mathrm{A} 11, \mathrm{~B} 75(15), \mathrm{Bw} 6$ \\
\hline 34. & $\mathrm{~A} 24(9), \mathrm{A} 10, \mathrm{~B} 15, \mathrm{~B} 73(15), \mathrm{Bw} 4, \mathrm{Bw6}, \mathrm{Cw} 4$. & 34. & Al1, A33, B44(12), B15, Bw4 \\
\hline 35. & $\mathrm{~A} 2, \mathrm{~A} 24(9), \mathrm{B} 13, \mathrm{~B} 73, \mathrm{Bw} 4, \mathrm{Bw6}, \mathrm{Cw}-$ & 35. & $\mathrm{~A} 2, \mathrm{~A} 24(9), \mathrm{B} 51(5), \mathrm{B} 35, \mathrm{Bw} 4, \mathrm{Bw} 6$ \\
\hline 36. & $\mathrm{~A} 24(9), \mathrm{A} 33, \mathrm{~B} 15, \mathrm{~B} 40, \mathrm{Bw6}, \mathrm{Cw}-$ & 36. & $\mathrm{~A} 24(9), \mathrm{A} 11, \mathrm{~B} 51(5), \mathrm{B} 35, \mathrm{Bw4}, \mathrm{Bw6}$ \\
\hline 37. & $\mathrm{~A} 2, \mathrm{~A} 24(9), \mathrm{B} 18, \mathrm{Bw} 6, \mathrm{Cw}-$ & 37. & $\mathrm{~A} 11, \mathrm{~B} 35, \mathrm{~B} 75(15), \mathrm{Bw} 6$ \\
\hline 38. & $\mathrm{~A} 24(9), \mathrm{B} 27, \mathrm{~B} 73, \mathrm{Bw4}, \mathrm{Bw6}, \mathrm{Cw}-$ & 38. & $\mathrm{~A} 24(9), \mathrm{A} 11, \mathrm{~B} 18, \mathrm{~B} 75(15), \mathrm{Bw} 6$ \\
\hline 39. & $\mathrm{~A} 2, \mathrm{~A} 24(9), \mathrm{B} 75(15), \mathrm{Bw6}, \mathrm{Cw}-$ & 39. & $\mathrm{~A} 2, \mathrm{~A} 11, \mathrm{~B} 13, \mathrm{~B} 77(15), \mathrm{Bw} 4$ \\
\hline 40. & $\mathrm{~A} 2, \mathrm{~A} 10, \mathrm{~B} 15, \mathrm{~B} 51, \mathrm{Bw} 4, \mathrm{~B} * \mathrm{w} 6, \mathrm{Cw}-$ & 40. & $\mathrm{~A} 2, \mathrm{~A} 24(9), \mathrm{B} 18, \mathrm{~B} 51, \mathrm{Bw} 4, \mathrm{Bw} 6$ \\
\hline 41 & $\mathrm{~A} 6602(10), \mathrm{A} 11, \mathrm{~B} 73(15), \mathrm{B} 77(15), \mathrm{Bw} 4, \mathrm{Bw6}, \mathrm{Cw}-$ & 41 & A11, A24(9), B27, B75(15), Bw4, Bw6 \\
\hline
\end{tabular}

